\title{
Lars Hætta's miniature world: Sámi prison op-art autoethnography
}

\begin{abstract}
This article examines a collection of miniature objects made by a Sámi political prisoner in Norway during the mid-nineteenth century as part of an educational programme now held in museum collections. It draws on recent developments in the theory of miniaturisation to consider them as examples of prison op-art autoethnography; communicative devices which seek to address broad and complex social issues through the process of the creation and distribution of semiophorically functionless mimetic objects of reduced scale and complexity, and which reflect the restrictions of incarcerated artistic expression and the questions this raises regarding authenticity and hybridity.
\end{abstract}

Keywords: miniaturisation, museums, autoethnography, Sámi, Norway

\section{Article}

In 1853, Lars Hætta, an 18-year old Sámi man, was sentenced to death for his part in the murder of two Norwegians during a violent political protest. His sentence was later commuted to life in prison and Hætta was, for the next 14 years, incarcerated in Akershus Castle in Oslo. There he spent his days in communication with academics from the University of Oslo (then Det Kongelige Fredriks Universitet [The Royal Frederiks Univeristy]), attempting to describe and depict his people and their lives, to build bridges where once he had set out to tear them down. This article explores a small collection of objects which he created whilst in captivity which are now split mainly between the Horniman Museum in London and the Norsk Folkemuseum in Oslo (alongside a miniature tent at the Pitt-Rivers Museum), and which provide insight not only into the life and mind of Lars Haetta, but into a much broader world of incarcerated expression and communication through miniaturisation.

It will examine the components of miniaturisation within its localised context, consider the series of decisions necessary to create these objects in dialogue with his jailers and draw inferences regarding his motivation and emphasis in the light of these factors. It will also examine the position of the objects as autoethnographic devices within an op-art anthropological methodology; the process by which anthropologists can use small ideas to assess and describe large-scale global questions, and consider what it is about this collection, and miniatures in general, which can provoke such unease among museum curators and scholars. It will end by considering the wider methodological implications of considering objects of this nature as op-art autoethnographic devices. 
Miniaturisation is a material culture practice which has been the subject of recent studies considering the cognitive and mechanical processes by which tiny objects have been created (e.g. Phillips, 1998; Mack, 2007; Evans, 2012; Knappett, 2012; Foxhall, 2014). This study of Hætta's collection of miniatures develops this in relation to recent work which posits miniaturisation to be a practice of not only the processes of creation, but also of the processes of distribution by which miniatures circulate among audiences (Davy, 2015; Davy, 2016). This draws on the notion of op-art anthropology, recently introduced by Sareeta Amrute, in which examination of small phenomena grants insight into far larger and more complex issues of global import. By starting with small, ephemeral things and expanding into grander scales, this rhetorical methodology "reveals connections among things not easily grasped by small, and then, large representational means" (2016).

Pursuing op-art anthropology, anthropologists can elucidate the colossal by focusing on the small. This article will posit that by creating the small in dialogue with the etic academics who held informal control over his imprisonment, Hætta was generating autoethnography; described by Mary Louise Pratt as a means of engaging with a self-referential commentary on colonised indigenous life in which artists "describe themselves in ways that engage with representations others have made of them" (1991), while simultaneously acknowledging concepts so potentially dangerous in context that they were almost impossible to address directly. Hætta, through his production of miniature material culture representations of wider cultural activities in direct engagement with academic Norwegian academic representations of his people, was combining these to practice op-art autoethnography.

\section{Lars Hætta}

Born in 1834, the third son of Jacob and Berit Hætta, Lars Hætta was a Sámi man of the community of Guovdageaidnu (known as Kautokeino in Norwegian) in the southern part of the Norwegian county of Finnmark at the northern tip of Norway, close to the Finnish border. In the early 1850s the community was predominately Sámi, with only a few Norwegian inhabitants, who predominately occupied positions of authority. Finnmark was at this time undergoing major social upheaval, as Norwegian immigrants and Scandinavian politics disrupted traditional Sámi reindeer herding territories and practices. Most devastatingly, the relatively recent large-scale introduction of alcohol to Sámi communities by state-licensed liquor traders was significantly exacerbating growing social problems, as a rapid increase in alcoholism among the Sámi caused widespread communal dislocation. Appeals to the Norwegian State Church for assistance passed without response; close associations between church officials and alcohol traders generated 
suspicion among the Sámi that these problems were not coincidental, but part of a concerted plan to drive the Sámi apart and seize their lands.

Into this widening fissure came Laestadianism, a movement within the Norwegian Lutheran church whose opposition to the Norwegian State Church and insistence on abstinence from alcohol found a popular audience among the Sámi communities of Finnmark. In 1851 a group of Laestadian activists, led by Lars' elder brother Mathis Hætta, attended church services in Skjervøy and Guovdageaidnu and disrupted proceedings, shouting down the priests. For this blasphemy they were tried in Alta, the regional capital, and sentenced to short periods of hard labour and heavy fines. Delays to proceedings resulted in their imprisonment continuing for much of 1852, and their inability to pay the fines led to the local sheriff, Lars Lohan Bucht, a corrupt official with a history of violence and extortion, to threaten to seize their reindeer herds as compensation.

Aslak Hætta, the second brother, was released in late 1852, after serving eight months for a twenty day sentence, and returned to Guovdageaidnu determined to take revenge on Bucht and the State religious authorities. He formed a group of 35 Sámi reindeer herders, all Guovdageaidnu residents and followers of Laestadianism, and began to organise protests against Bucht, who had arrived in Guovdageaidnu the previous year having fled his native Sweden ahead of allegations of corruption and brutality. Aslak designated Bucht "the Great Satan", and also directed his preaching against local liquor traders and religious authorities. Aslak preached that he was "ett med den treenige Gud og at treenigheten var ett med ham og bodde i hans hjerte"; "one with the true God, and that the Trinity was one with him and lived in his heart", and that thus his actions were incontestably and unarguably directed by God.

Faced with the threat of forced conversion to the State Church by Bucht, Aslak Haetta and his friend Mons Somby led his followers, including teenaged Lars, to the church at Guovdageaidnu on the evening of 8 November 1852. Aslak positioned himself behind the crowd, thrashing those who wavered with birch rods. The pastor, the recently arrived Fredrik W. Hvoslef, was seized by the crowd along with his parishioners and family and whipped through the streets of the village. Only his wife, heavily pregnant, was spared. The procession then marched to Bucht's home, and when he emerged he was set upon and beaten to death. The local trader, a Norwegian alcohol importer named Carl John Ruth, attempted to intervene and was also killed. The mob then looted his store and set it on fire. Alsak was heard to propose that the church also be burned down, and another Laestadian called for the entire community to be razed to the ground. 
Alarmed by the violence of the protest, Sámi members of the community unaffiliated with the Laestadians fled to the neighbouring village of Ávžži, and raised the inhabitants there to organise a counter-attack against the rebels. 19 Sámi participated in the counter-attack, resulting in a running battle with fists, clubs and fence-posts through the streets of the village. After heavy fighting Aslak Haetta's group, much diminished through desertion, were subdued and sent to Alta for judgment. Many people were badly injured; a woman struck on the head died after two days, and a man later died of his injures during transportation to Alta.

In Alta, the rebels stood trial for murder. Somby and the Hætta brothers were among five participants sentenced to death; others were awarded lighter sentences for their part in the uprising, varying from between life sentences and 8 months hard labour. Five were acquitted entirely. Somby and Aslak Hætta were beheaded in Alta before a large crowd policed by a Norwegian military detachment on 10 October 1854 and buried in unmarked graves, their decapitated heads sent to the University at Oslo as scientific specimens. Lars Hætta and the two other condemned prisoners received reprieves from King Oscar due to their young age, and were sent to prison in Trondheim alongside their comrades who had been given less severe sentences (Aarseth, 2009 i).

While in Trondheim, the group came to the attention of Professor Jens Andreas Friis, Reader in Sámi languages at Det Kongelige Fredriks Universitet, who was seeking Sámi participants for his research and saw the Guovdageaidnu prisoners as an opportunity to learn more about the Finnmark Sámi. At Friis' request, Lars and six other male prisoners were transferred to Akershus Castle in Oslo, where Friis was charged with providing them with a "Christian education". Friis was an early Norwegian anthropologist, focused on linguistics and folklore, who had trained as a theologian in his youth. During the 1840s he had worked extensively with Sámi communities in both Norway and Finland. He was not only fluent in Northern Sámi, but also familiar with the unpublished manuscripts of Lars Laestadius, founder of Laestadianism, and his tales of his travels in Finnmark. A sympathetic observer therefore, he was publically opposed to the policy of the Norwegianization of the Sámi, and in particular to the missionary activities of the Norwegian State Church, whom he criticised for teaching the Bible to the Sámi in Norwegian rather than their native language, believing this to be a blasphemous approach (Mathisen, 2000:105-106). In Hætta, Friis found a willing collaborator, and it is easy to see how they rapidly became partners in both academic and religious research.

Cut off from his homeland, relatives and most of his people, in captivity Hætta turned his attentions wholeheartedly to scholarly and religious pursuits. His faith, no longer guided by his 
brother's claims to be acting as the will of God, led him to explore the Bible for himself, obtaining a recent translation of the New Testament into the Northern Sámi language by N. J. Stockfleths. He came swiftly to repudiate his youthful behaviour, expressing anger and regret for his participation in the riot. Instead, he committed to working with Friis and others at the University to produce extensive accounts of Sámi life, and he also began to work on his own translation projects. The most famous of his works was the first translation of the Bible into the Northern Sámi language, but this forms only a small part of the extensive archive he produced.

Hætta remained in prison until 1867, when he was granted permission participate in a research expedition to Finnmark led by Friis. The terms of this permission granted Hætta the right to remain in Finnmark as a free man once the expedition concluded. At this point he was the longest serving prisoner of the Guovdageaidnu uprising, having spent fourteen years in Trondheim and Akershus, the last two years without any Sámi companions. Following his release he settled once more in Guovdageaidnu and subsequently married. His Sámi Bible and a number of other works, including collaboration on a Sámi dictionary with Friis and several books of prayers, hymns and religious teachings, were published before his death in 1896 (Aarseth, 2009 ii).

Alongside the extensive archives Hætta left at the University was a collection of hand-carved miniature objects. The story of Lars Hætta and his educational work explains the origin of this collection, which today is split between the Norsk Folkemuseum in Oslo, the Pitt-Rivers Museum in Oxford and the Horniman Museum in South-east London. This collection was made as part of Hætta's engagement with Friis' knowledge exchange programmes during his captivity, and tell an important and powerful story of semiotic engagement with structural power imbalances through the medium of miniaturisation.

\section{The Hætta miniatures}

Hætta's miniatures are exclusively of Sámi objects; predominately of everyday items such as spoons, bowls, buckets and barrels, with a specific focus on saddles, sledges and other equipment associated with reindeer herding. He carefully made them to approximate scale, and labelled them so that his audience would know what was intended in a delicate copperplate handwriting. They are not however consistently scaled as a group; they were never intended to produce a Sámi diorama, but were scaled for individual purposes and audiences. 
The language he used for the labels is Sámi, but scattered with a mixture of Norwegian, including colloquial variations on Norwegian words common in Finnmark; as a translator, Hætta would have been fluent in both languages, and his choice of a Sámi/Norwegian mix probably reflects his desire to educate his audience in the Northern Sámi language words for such staples of reindeer-herding life, perhaps tinged with discomfort in using solely Norwegian, his secondlanguage, to describe objects which typified traditional Sámi material culture. It is notable that none of these objects reflect historic Sámi religions or rituals; as a devout Laestadian Christian, these would have been of little interest to Hætta; instead he made miniatures of the everyday life of the Sámi people of his home community, and must have presented or sold them to the Norwegian academics with whom he worked as visual aids to support his detailed notes on Sámi life.

The Hætta collection forms a body of specific daily implements, made using where possible traditional materials and techniques, but simplified and augmented to account for both the small size of the objects in the collection and their intended use as teaching aides. The largest objects are the tents (NFSA.3744; PRM 1884.1.3), made from paper rather than the hide normal to the full sized tent (Påskrift), on wooden frames (uksa sielbma). There are also wooden reindeer sleds; known as the boat-sledge and generally among the Sámi as pulkea and running approximately $7 \mathrm{ft}$ $(2 \mathrm{~m})$ in length, the Hætta collection has two miniature versions. The Horniman sledge (HMG $32.53,14 \mathrm{~cm}$ ) is an open-top single rider sled (Vuojjem Geris dashe Pulkke / Battaliekeoo), which comes attached to a wooden reindeer figure which is described by the museum as a prop created at a later date in an attempt to illustrate a dioramatic use of the material culture of Sámi reindeer herders in the mid-nineteenth century for an audience in a pedagogical capacity. The Norsk Folkenmuseum sledge (NFSA.4027, 14cm) has the top enclosed (lokke geris); sledges of this type were used by Sámi herders to transport valuables and food, the enclosure protecting the contents from the elements whilst on the move.

The rest of the collection is indicative of the equipment of a mobile reindeer herder, including spades (Goaivvo; NFSA.3955, 9cm), a selection of bowls (Garre NFSA.3977), barrels (Gagga; NFSA.3960,9cm) and a series of ladles and long-handled cups of various sizes (Gukse and Nappa; NFSA.3977, 7cm, NFSA.3958, 6cm), Sámi drinking vessels transliterated more recently as guksi and used for coffee; as a temperance activist, it is likely that Hætta would have had a long association with coffee paraphernalia, drink which was extremely popular in Norway in the nineteenth century. There are a series of lidded discs (Vuosta lokkek; HMG nn19776, 3-6cm), which probably depict presses for reindeer cheese, and two sets of skis and ski poles (Sabetak / 
Gavrre Soabbe; NFSA.3970, 12cm). Other materials are very specific to the management of reindeer, such as the miniature versions of specialist saddles (Spagak; NFSA.3972), carefully carved and bent with leather straps. These are accompanied by saddle packs, such as the cradle (Basso Gisa; NFSA.3976) of wood and hide, and the saddle pannier (lokke aeber / jorba giisa; HMG nn11104), in which a circular or oval boxes contains padded drum-like objects, packed for transport. (see Vorren \& Manker, 1976; Spencer, 1978). Even the wooden reindeer figure, so often described in museum notes as a "prop", wears perfectly tailored colourful felt trappings sewn by Hætta (Avohas).

The majority of the collections, both at the Horniman and the Norsk Folkemuseum, are domestic and conspicuously impersonal in nature. There is no clothing, no individualistic decoration, and nothing religious, either from a Sámi shamanistic, Norwegian State Church, or from a Laestadian perspective, such as drums or idols (cf. Spencer, 1978:84-100). This lack of religious imagery is hardly surprising given Hætta's contentious history of religious activism, but it does render the collection as one which is ostensibly purely functional in appearance. In this way, Sámi identity of the miniatures is rooted firmly in the aesthetics, technology and mechanics of the material culture itself, not in its imagery or cosmology; it states that the Sámi are reindeer herders and reindeer-herding is essential to being Sámi. It is therefore no surprise in this context that Bucht's threat to confiscate the rebels' herds provoked such outrage.

By omitting supernatural elements, an anathema to a devout Christian such as Hætta, the miniatures illustrate a simple, practical, pastoral, way of life as typically Sámi and the Sámi as exemplars of this way of life. They do so with the conscious understanding that most of the audience will be comprised by educated Norwegians for whom this will likely be their first and perhaps only exposure to the Sámi. It would almost certainly be the only such exposure to have been produced by a Sámi as opposed to second hand through non-Sámi sources, with all the risks of accidental or deliberate misrepresentation that entailed.

Although there is some correspondence suggesting that parts of the collection date to 1861, the bulk of the material was purchased by the University in 1863, some ten years into Hætta's sentence. After his release they were retained in Oslo as teaching aids and presumably curiosities, becoming part of the founding collection of the Ethnographic Museum in Oslo. In 1957, during a rationalisation of Norwegian museum collections, they were reclassified as "folk art" and transferred to the Norsk Folkemuseum. This transfer probably reflects a political decision to move the Sámi collections from the Ethnographic collections, where they were contextualised as "the other", into the Norwegian Folk Museum to reflect a modern understanding of Sámi as an 
integral part of Norwegian life, thus retrospectively authenticating the Norwegianness of Hætta's identity, quite possibly in opposition to his original wishes.

This was one of a number of etic re-categorisations to which the collection was subject, later curators imposing new meanings and interpretations onto Hætta's miniatures according to their own academic understandings of object categories rather than Hætta's original intentions. For more than a century the collection remained unregistered in any Norwegian museum catalogue, only receiving official recognition in 1979. At some stage and thorough unknown means the collection was broken up; some of Hætta's miniatures found their way to Britain; a tent was accessioned by the Pitt-Rivers Museum in 1884, and a broad selection entered the private Blackmore Museum in Salisbury at an unknown date. Others disappeared, and although registers vaguely suggest that there may once have been as many as 160 Hætta miniatures, only 33 objects now remain with the Norsk Folkemuseum. When the Blackmore Museum closed in 1932 that collection too was dispersed and parts of it can now be found in several institutions. The largest intact Hætta collection in Britain today is at the Horniman Museum, where there are 11 objects. Apart from a pair of miniature skis and the reindeer with attached sledge, this collection too remained uncatalogued until the last decade of the twentieth century.

The long failure to properly catalogue the collection betrays, I think, a discomfort felt among curators in dealing with a collection of this nature. Miniatures by their very nature are discomforting, portraying a functional object but too small to be functional in their own right. Marry this to the circumstances under which they were created; the incarceration, the potential for coercion, their inception by anthropologists and scholars rather than as indigenous artistic expressions, and they become problematic indeed. Speaking of Greenlandic Inuit miniatures, Danish archaeologist Morten Porsild wrote that these objects "find their way to museums, just where they ought not to be, as generally, with a few exceptions, they are devoid of all scientific value" (1915:233). The reluctance of British and Norwegian museum curators to properly catalogue Hætta's collections stems perhaps from a similar reluctance to acknowledge the unusual hybridity of their creation, the perceived inauthenticity of the circumstances of their conception and ultimately the troubling lack of practical functionality inherent in all miniatures.

\section{Interpreting Hætta's collection}


If miniaturisation is a process of communication, through which non-verbal knowledge may be stored and transmitted by miniature objects, then Hætta's work can be understood as a means of education through material culture. The miniatures reflect this ability, but simultaneously complicate the process because Hætta was not free to miniaturise what he wished; although by the end of his captivity he was granted substantial license as a trusted prisoner, he was always under observation, and never at complete liberty to express himself as he might have done in his ancestral home. It was a captive medium of expression, one not wholly indigenous to the Sámi, but one that was also not alien to Hætta, occupying a conflicting, hybrid, middle-ground.

Miniature objects are by their nature fascinating, tactile and experiential. They reward bodily engagement, and can appear facile and non-threatening when taken out of context. This condition makes them valuable art objects to a prisoner, who may be free to create miniatures with the limited resources available to them of things that would be forbidden at larger scale. In combination with the inherent lack of practical functionality, miniaturisation can allow for the expression of intangible qualia, such as regret, anger or hope. Understanding how these qualia can manifest is reliant on examination of the affordances of the miniature, the qualities which give it structure and which can provoke corresponding qualia, emotional responses, in a viewing audience.

These affordances have a number of effects; one of the most significant is that the mimetic affordances are skeuomorphic in nature. Skeuomorphs are objects whose design features adopt the appearance of the design features of another object for reasons unrelated to their mechanical functionality, in order to make use of that object's networks of indexical relations ( $c f$. Knappett, 2002). In Hætta's miniatures this is true throughout: the gagga barrels are incapable of holding material, being solid blocks of wood carved into a barrel shape. The handwritten labels which describe them "text-aid" ( $c f$. Hawkes, 1954) this impression, so that an audience sees a barrel, reads gagga, and draws on a barrel's network of relations to think of a barrel, rather than focus upon the skeuomorphic reproduction of a barrel in miniature which is actually before them. An audience does not see the solid miniature, they see the barrel, the gagga, with all of the indexical qualities of containment and transportation such an object permits.

This results in a subtle semiophoric effect. Semiphores are objects which are "without use"; which have abandoned mechanical activity for a state in which their functionality becomes one of representation, not utility ( $c f$. Pomian, 1990). In effect these objects lose their original identity as a practical tool and become a synecdoche of a wider concept; they no longer represent themselves, but instead stand in for something larger and less tangible. Unlike other objects, with 
miniatures this "useless" state is not conferred by the object's situation, but is a core design feature embedded in the object from its original conception. The semiophoric qualities of Hætta's skeuomorphic objects allows them to be useless and thus permits the creation of new links with an audience through their diminutive tactility. The garre bowls do not have the practical ability to hold liquid, but instead adopt the affordances of practical bowls in an illusory manner, in order to allow for the creation of an imaginative impression not only of liquid, but of the motions of liquidity; the pouring and stirring and drinking that use of the full-sized bowl would require.

The skeuomorphic and semiophoric nature of the miniatures allows them to act as objects of non-verbal communication. Their diminutive tactility and their disengagement with human scales makes them attractive icons of Sámi material culture. I believe that Hætta, held captive in Akershus Castle hundreds of miles from his home in an alien climate, culture and language, understood and intended them as such; it would explain his selective choice of mimetic subject, omitting those aspects of modern Sámi culture to which he stood opposed and focusing instead on what he may have considered to be the purer, more pious aspects of the Sámi people and their reindeer herding livelihoods. The objects he is miniaturising are all based on traditional Sámi prototypes, without transcultural Norwegian influences. They do not show the actuality of the increasingly culturally-mixed Guovdageaidnu against which Hætta and his companions rebelled, but a more personal reality. Nor of course do they show advancement over time; as a prisoner Hætta's frame of reference on Sámi life was restricted and frozen, cut off from modernisation or adaptation. Hætta was also however keenly interested in education, in particular the transmission and preservation of Sámi lifestyles and ideas, and in this sense his miniatures are quasi-scaled depictions of a particular interpretation of Sámi life made for pedagogical purposes.

To study miniatures in this context requires examination of three elemental operations at work within the process. These are mimesis, scaling and simplification, and together they can provide insight into the motivations of Hætta as an artist, the emphasis he wished to place on the objects in relation to an audience and thus the ideological effect he hoped to achieve via the process. The mimetic qualities of these miniatures has been discussed; their focus only on certain aspects of Sámi culture and their preservation of only specific parts of more traditional Sámi technology. The scaling is important; far too small to be functional or operative on practical terms, these are easily carried, moved and manipulated. Some at the Norsk Folkemuseum are packed into carrying cases, implying an intention for them to be safely transported, perhaps by Friis moving from class to class. They are the right size to be held in the hand, played with and figuratively 
inhabited, the observer, for a short time, engaging with the romantic imagination of themselves as a reindeer herder thundering across the tundra in their own covered sled and thus forming sympathetic emotional links between viewer and Sámi culture. The simplification lies in their lack of mechanical functionality; these guksi are not made to hold coffee boiled over a fire in the depths of an Arctic winter or the goaivvo to shovel snow in order to survive; instead they are made to be weighed and situated on a desk or in a glass case, held in a warm classroom or gallery hundreds of miles from the nearest reindeer herd. They carry only those affordances necessary to form the mimetic link, without decoration or adaptation, without modernisation or hybridity.

Not only was Hætta clearly selective in what material culture objects he chose to depict, and what aspects of his life he considered relevant, he was also selective in his initial audience. Hætta's imprisonment led him into an association with academics from the University who were interested in using recently developed scientific (and pseudoscientific) techniques to learn more about the Sámi. His brother's head had been sent to Oslo for exactly this reason, to be studied alongside other heads from around the world as part of the now long-discredited study of phrenology, measuring traits based on head shape, and later in the then cutting edge and poorly understood field of early evolutionary biology developing from Darwin's On the Origin of Species, published in 1859. This entailed study of indigenous peoples in an attempt to understand the history of mainstream European society through comparative analysis, on the erroneous assumption that technology is absolute rather than relative. It was in this light that Hætta's work with Friis at the University took place, during the period which saw the birth of anthropology as a discipline. In these early anthropological processes the indigenous participants rarely experienced the appreciation or understanding for their contribution which Hætta received from Friss, and behaviour took place that we would not consider not only unethical, but reprehensible. As an example, even as Lars Hætta worked with Friis,, the same university traded his brother Aslak's head for the skulls of two Inuit people from the University of Copenhagen in 1856; Aslak's skull was considered a "duplicate” of Mons Somby's head. In 1996 a movement to return the heads of both Aslak and Somby sought to locate the missing remains in Denmark, and the following year both heads were returned to Alta for burial alongside their bodies, which still lie in unmarked graves outside the Kåfjord Church.

Friis position as a theologian and sympathetic scholar of the Sámi allowed him to continue his work with Hætta until the latter's death. The collection of miniatures most likely developed through their relationship, Hætta producing the miniatures as models for examination and study as well as teaching aides for future generations of Norwegian scholars of the Sámi. They are thus 
examples of autoethnography; things which were created not solely through indigenous agency, but in the direct expectation of and through engagement with the expectations of a dominant colonial authority. Friis may not have recognised or realised his influence over Hætta's productions, but it nevertheless is essential to their composition. Without the combination of Friis and Hætta, these objects simply would not exist.

This is not however to diminish Hætta's agency over the miniatures. It may offer some explanation as to why there is no evidence of the encroaching Norwegian influence over Sámi life, but it also reflects Hætta's own preoccupation with the cultural well-being and survival of the Sámi people, a desire to preserve and educate Norwegians of influence and garner favour and support for Sámi autonomy and rights among those potentially placed to influence the situation. His participation in the research, of which these miniatures form a significant part, certainly helped secure his release and return to his homeland, for which his letters make clear he had never stopped yearning (Aarseth, 2009ii). It is also important however not to be too cynical about Hætta's motivations. His concern for the Sámi was genuine and heartfelt, as demonstrated by his lifelong efforts to support Sámi religious instruction, while his reported enthusiasm for his work with Friis as a form of atonement for his youthful transgressions makes these miniatures emotional expressions of repentance and pedagogical intent.

The miniatures are therefore no less authentic for Friis' involvement. He may have acted as a catalyst for Hætta's creation of the miniatures, but they are simultaneously vigorous expressions of Hætta's own personal desire to project, preserve and display Sámi culture. Contrary to Porsild's gloomy admonishment, Hætta's miniatures should be in museums and are far from devoid of scientific value. Not only are they intriguing insights into Sámi material culture of the mid-nineteenth century, and expressions of ideology from an imprisoned Sámi activist, that is also the explicit intention, and thus the scientific methodology, under which Hætta made them. He knew they would be retained and used by the University, with whom he had worked for so many years. He knew how Friis used them and intended to use them, and although it is presumptive to speak for a man long dead, it is likely that he would have been appreciative that 150 years after they were made, 120 years after his own death, when Sámi and Norwegian life has been altered almost beyond recognition from the traditional world Hætta knew, his miniatures were still being used to educate people about the Sámi and their reindeer herding material culture.

For that is where the unease lies in displaying and working in museums with miniature objects such as the Hætta collection. Unlike the vast majority of museum collection material culture, the 
blankets and clubs, swords and shirts, which were used in one indigenous environment and then transplanted and semiophorically stripped of their original context by curators, miniatures such as these were often made explicitly for museums (or similar) to display. They were made to fascinate, to intrigue, to educate and to portray. They were made with us as an audience in mind, and they constantly play tricks on us through their selective use of certain affordances over others. Through their manipulative skeuomorphic qualities, through their essentially useless semiophoric qualities and through their autoethnographic origins they tell us precisely what their creators wanted us to know. Curators are used to manipulating museum objects; seriating and cataloguing them, arranging them into neat categories based on functionality or material, presumed cultural origin or age. They can then use them however they see fit, creating dynamic dioramas or exploratory displays or placing them literally on a pedestal as if they were and always have been an art object to be observed rather than a practical, useful object of everyday life.

Miniatures defy this approach, refusing to be easily catalogued or interpreted because their functionality is representational rather than practical, and thus they have safely discarded mechanical requirements to take on invisible, intangible dimensions which disrupt neat curatorial narratives. Operating beyond the immediate environs of their creation, Hætta's miniatures continue to fascinate and mystify, entering new contexts and interacting with them directly and indirectly. They "torque", (cf. Pinney, 2005), twisting in their new environments to fulfil new purposes yet still retaining enough independence by virtue of their non-practical affordances to retain some of Hætta's original intentionality.

This then is op-art autoethnography; a means Hætta found of simultaneously expressing the cultural identity which was taken from him in captivity and addressing more complex shifts in the society of Finnmark. He was able to register in some small way his protest at what he saw as impious changes to Sámi society under Norwegian influence and preserve through an extensive body of work his ideal of the reindeer herder; a man unaffected by the changes in Sámi society in mid-nineteenth century Norway, uninterrupted by alcoholism or corrupt officials, by the enclosing of land or imposition of what he considered to be blasphemous religious services. He was able to distribute these miniatures to men of knowledge and science, and to learn from them knowledge sufficient to pursue his goal of missionary work among his people.

This was possible though the inherent semiophoric uselessness of the objects he created, their skeuomorphic iconic relationship with Sámi material culture and the corresponding indexical relationship with the Sámi themselves. The miniatures have travelled, beyond even those audiences Hætta intended, torqueing as they did so, still fascinating and generating an unease 
among curators unsure of their authenticity or origin. This study of Hætta's collection of miniatures provides a methodology for studies of similar collections of miniaturised material culture; a process of affordance analysis and consideration of context and audience that highlight the specific powers of op-art representation of these diminutive objects, as well as the complexities of the colonial/colonised relationship which dominated the semi-coercive, autoethnographic context under which Hætta worked. From 2018 they will continue to fascinate and unsettle visitors and curators alike in the new galleries at the Horniman, drawing in audiences through their diminutive affordances and leaving them a little more knowledgeable, a little more educated, about the world of Lars Hætta.

\section{Acknowledgements}

The author wishes to thank the Horniman Museum, the Pitt-Rivers Museum and the Norsk Folkemuseum, with especial thanks to Dr. Leif Parelli and Dr. Sophie Mew.

\section{Bibliography}

Aarseth, B i (2009). "Aslak Hætta". Norsk Biografisk Leksikon. Accessed online at https://nbl.snl.no/Aslak_H\%C3\%A6tta

Aarseth, B ii (2009). "Lars Hætta". Norsk Biografisk Leksikon. Accessed online at https://nbl.snl.no/Lars $\mathrm{H}_{0} \% \mathrm{C} 3 \% \mathrm{~A} 6 \mathrm{tta}$

Amrute, S (2016). Op-Art Anthropology and my Grandmother's Shoe. Paper presented at Small Things, $115^{\text {th }}$ AAA Annual Meeting, Minneapolis. 19 November 2016.

Davy, J (2015). A LEGO Snowmobile and the Elements of Miniaturisation. Anthropology Today, Vol. 31, No.6 (Dec, 2015)

Davy, J (2016). Miniaturisation: a study of a material culture practice among the indigenous peoples of the Pacific Northwest. Unpublished PhD thesis. University College London, Department of Anthropology. 
Evans, C (2012). Small devices, memory and model architecture: Carrying knowledge. Journal of Material Culture, Vol.17, No.4, 369-387

Foxhall, L (2014). Introduction: miniaturization. World Archaeology, Vol.47(1), 1-5.

Hawkes, C (1954). Archaeological Theory and Method: Some Suggestions from the Old World. In American Anthropologist, Vol.56 (2), 155-168

Knappett, C (2002). Photographs, Skeuomorphs and Marionettes: Some Thoughts on Mind, Agency and Object. In Journal of Material Culture, Vol.7 (1), 97-117

Knappett, C (2012) Meaning in Miniature: Semiotic Networks in Material Culture. In Excavating the Mind: Cross Sections through Culture, Cognition and Materiality, eds. M. Jensen, N. Johanssen \& H. J. Jensen, 87-109. Aarhus: Aarhus University Press

Mack, J (2007). The Art of Small Things. London: British Museum Press

Mathison, S R (2000). Changing Narratives about Sami Folklore - A Review of Research on Sami Folklore in the Norwegian Area. In Sami Folkloristics, ed. J. Pentikäinen, 103-130. Åbo: Nordic Network of Folklore

Phillips, R B (1998). Trading Identities: The Souvenir in Native North American Art from the Northeast, 1700-1900. Seattle: University of Washington

Pinney, C (2005). Things Happen: Or, From Which Moment Does That Object Come?. In Materiality, ed. D. Miller, pp.256-272. Durham \& London: Duke University Press

Pomian, K (trans. E. Wiles-Portier) (1990 [1987]). Collectors and Curiosities: Paris and Venice, 1500-1800. Cambridge: Polity Press

Porsild, M P (1915). "Studies on the Material Culture of the Eskimo in West Greenland" in Meddelelser on Gronland, Bind LI, No.7

Pratt, M L (1991). Arts of the Contact Zone. In Profession, 33-40

Spencer, A (1978). The Lapps. Vancouver: Douglas David \& Charles Ltd.

Vorren, O \& Manker, E (1976). Same-Kulturen. Tromsø, Bergen \& Oslo: Universitetsforlaget 
